CLIN. EXPL. METASTASIs, 1989, voL. 7, No. 3, 265-276

\title{
Characterization of thrombospondin synthesis, secretion and cell surface expression by human tumor cells
}

\author{
JAMES VARANI $\ddagger$, BRUCE L. RISER $\dagger$, LISA A. HUGHES $\dagger$, \\ THOMAS E. CAREY§, SUZANNE E. G. FLIGIEL\| \\ and VISHVA M. DIXIT $\dagger$ \\ Department of Pathology $\dagger$, and Otolaryngology $\$$, \\ University of Michigan Medical School, Ann Arbor, MI48109, U.S.A. \\ and Department of Pathology $\|$, VAMC-Wayne State University, \\ Allen Park, MI 48101, USA.
}

(Received 12 January 1988; accepted 16 May 1988)

\begin{abstract}
Previous studies have shown that thrombospondin (TSP) is an adhesion factor for some human tumor cells. The previous studies have shown further that tumor cells which utilize TSP as an adhesion factor also synthesize it. This study continues the effort to understand how TSP production and expression are regulated in human tumor cells and the consequences of this for the cells. It is shown that differences among cell lines in their capacity to biosynthesize TSP are associated with differences in TSP specific mRNA levels. This indicates that biosynthesis is regulated at the transcriptional level. There is also a direct relationship between TSP biosynthesis and secretion into the culture medium and expression at the cell surface. The cells which are the most biosynthetically active secrete amounts of TSP into the culture medium that are sufficient to elicit a detectable response in the cell-substrate adhesion assay. The kinetics of TSP secretion by these cells are in accord with the kinetics of attachment and spreading of the same cells in the absence of exogenous adhesion factors. These data are consistent with the idea that endogenously produced TSP promotes the adhesion of the cells which synthesize it in an autocrine manner.
\end{abstract}

\section{Introduction}

Thrombospondin (TSP) is synthesized by a variety of different cell types and incorporated into the extracellular matrix (ECM) of these cells $[11,15,16,19,24$, 31]. Like other components of the ECM, TSP stimulates cell attachment and spreading [21, 27, 29-31]. Studies in our laboratory have focused on the role of TSP in human tumor cell biology. Our studies have shown that certain tumor cell lines synthesize TSP [29] and concomitantly express surface binding sites for TSP [20]. The production of both the ligand and its receptor by the same cell provides a mechanism whereby the ligand could be used as an endogenous adhesion factor.

This study characterizes TSP production in a number of human tumor cell lines derived from squamous carcinomas, melanomas and gliomas. It is shown that there is a direct relationship between TSP biosynthesis and the amount of TSP-specific mRNA in the cells, suggesting that biosynthesis is regulated at the transcriptional level. There is, in addition, a direct relationship between TSP biosynthesis and secretion into the culture medium and cell surface expression. The cells which are

$\ddagger$ To whom correspondence should be addressed. 
the most biosynthetically active (squamous carcinoma) produce amounts of TSP that are sufficient to elicit a cell-substrate adhesion response. Taken together, these results support the idea that endogenously synthesized TSP may promote tumor cell adhesion in an autocrine type of manner.

\section{Materials and methods}

Cells

A number of human squamous carcinoma, melanoma and glioma lines were used. The isolation and characterization of these lines have been described previously $[2,12,14]$. These lines were used in our recent studies characterizing the cell-substrate adhesion response to TSP [29, 30]. TSP binding studies have also been conducted using some of the same cell lines. These studies showed a direct correlation between TSP binding and TSP-induced cell-substrate adhesion [20]. For this study, all of the lines were grown in monolayer culture under identical conditions. 'The growth medium was minimal essential medium of Eagle and Earle's salts (MEM) supplemented with non-essential amino acids, 15 per cent fetal bovine serum, $100 \mathrm{U} / \mathrm{ml}$ of penicillin and $100 \mu \mathrm{g} / \mathrm{ml}$ of streptomycin. Growth was at $37^{\circ} \mathrm{C}$ in medium equilibrated with 5 per cent $\mathrm{CO}_{2}$. The cells were subcultured by trypsinization as required.

\section{Reagents}

TSP was purified from the supernatant fluid of thrombin-activated platelets as described previously [4]. The purifies TSP migrated as a single protein band with an apparent $M_{\mathrm{r}}$ of $180 \mathrm{kD}$ when examined by sodium dodecylsulfate-polyacrylamide gel electrophoresis (SDS-PAGE) under reducing conditions.

Rabbit polyclonal antibodies to TSP and three different monoclonal antibodies to TSP were used. The three monoclonal antibodies used were antibody A2.5, directed against the heparin-binding domain of the TSP molecule; antibody A6.1, directed against an epitope located within the 70-kD trypsin-resistant core of the TSP molecule; and antibody A4.1, directed at an epitope within a 45-kD fragment that is itself within the $70-\mathrm{kD}$ trypsin-resistant core. The production and characterization of the polyclonal and monoclonal antibodies have been described previously $[5-7,10,31]$. The monoclonal antibodies were purified from ascites fluid by ammonium sulfate precipitation followed by affinity chromatography on protein ASepharose. Purity was determined by SDS-PAGE. The rabbit polyclonal antibody against TSP was purified by affinity chromatography on protein A-Sepharose. Specificity for TSP was confirmed by solid-phase radioimmunoassay performed with immobilized antibodies and TSP iodinated with $\mathrm{Na}^{125} \mathrm{I}$ and iodobeads.

\section{Biosynthetic labeling}

The cells were grown in $100-\mathrm{mm}$ (diameter) culture dishes to an approximate density of $1 \times 10^{7}$ cells per dish. The cells were washed and incubated for $30 \mathrm{~min}$ in methionine-free, serum-free minimal essential medium (Flow Laboratories, McLean, VA) followed by a 60-min incubation in the same medium supplemented with $100 \mu \mathrm{Ci}$ per dish of $\left[{ }^{35} \mathrm{~S}\right]$ methionine $(1000-1400 \mu \mathrm{Ci} / \mu$ mole) (NEN, Boston, MA). After the $60-\mathrm{min}$ biosynthetic pulse, the cells were again washed and incubated for a further $4 \mathrm{~h}$ in complete medium. The 4 -h chase cells were lysed in a solution of phosphate-buffered saline (PBS) containing three detergents (1 per cent Triton X$100,0.5$ per cent sodium deoxycholate and 0.1 per cent SDS; all obtained from 
Sigma) and protease inhibitors including $20 \mathrm{mM}$ EDTA, $5 \mathrm{mM} N$-ethylmaleimide, $2 \mathrm{mM}$ phenylmethylsulfonyl fluoride (PMSF) and $10 \mu \mathrm{l} / 10 \mathrm{ml}$ of a protease inhibitor cocktail containing leupeptin $1 \mathrm{mg} / \mathrm{ml}$, antipain $1 \mathrm{mg} / \mathrm{ml}$, benzamidine $10 \mathrm{mg} / \mathrm{ml}$, aprotinin 10000 kallikrein-inactivating units $/ \mathrm{ml}$, chymostatin $1 \mathrm{mg} / \mathrm{ml}$ and pepstatin $1 \mathrm{ml} / \mathrm{ml}$, as described by Ronnett et al. [22] in studies on the insulin receptor. All of the protease inhibitors were obtained from Sigma. The 4-h chase media were also supplemented with the detergent/protease inhibitor mixture by adding a onequarter volume of a 5-fold concentrated solution. The cell lysates and chase media were frozen at $-80^{\circ} \mathrm{C}$, thawed and clarified by ultracentrifugation $(37000 \mathrm{~g}$ for $60 \mathrm{~min}$ ). Immunoreactive TSP was precipitated with a $1: 100$ dilution of the rabbit anti-TSP and protein A-Sepharose (Sigma) according to the protocol of Ruddon et al. [23]. Normal rabbit serum served as a control. The washed immunoprecipitates were divided in half and eluted with boiling $(5 \mathrm{~min})$ in 2-fold concentrated Laemmli SDS-PAGE sample buffer [13], either with or without 2 per cent 2mercaptoethanol. The immunoprecipitated material was fractionated on a 3-10 per cent polyacrylamide gel employing the Laemmli system. Radioactive bands were visualized by autoradiography with $\mathrm{En}^{3}$ Hance (NEN), exposing the dried gels to Xray film (Kodak XAR-2) for 2 days.

\section{Preparation of RNA and Northern blot analysis}

Total RNA for Northern blot analysis was prepared from the cells using the method of Chirgwin et al. [3]. Typically, yields from one $150-\mathrm{cm}^{2}$ flask were between 100 and $200 \mu \mathrm{g}$ of total RNA.

For Northern blot analysis, total RNA samples and an RNA ladder (Bethesda Research Laboratories), which served as a molecular weight marker, were electrophoresed through an agarose gel formed in $2.2 \mathrm{M}$ formaldehyde $-20 \mathrm{mM} 3-(N-$ morpholino)propanesulfonic acid (MOPS) buffer, $\mathrm{pH} 7 \cdot 25,0.1 \mathrm{mM}$ sodium acetate, and transferred directly into nitrocellulose in $3 \mathrm{M}$ sodium chloride $-0.3 \mathrm{M}$ sodium citrate as described by Thomas [26]. The filters were baked in vacuo at $80^{\circ} \mathrm{C}$ for $2 \mathrm{~h}$ and pre-hybridized in 40 per cent formamide- $0.6 \mathrm{M}$ sodium chloride- $60 \mathrm{mM}$ sodium citrate $5 \times$ Denhardt's solution $(1 \times$ Denhardt's solution $=0.02$ per cent bovine serum albumin-0.02 per cent Ficoll-0.02 per cent polyvinylpyrrolidone)herring sperm DNA $[100 \mathrm{mg} / \mathrm{ml}-0 \cdot 1$ per cent sodium dodecylsulfate (SDS) $-0 \cdot 2$ per cent sodium pyrophosphate-poly $(\mathrm{A})(1 \mu \mathrm{g} / \mathrm{ml})]$ at $42^{\circ} \mathrm{C}$ for at least $3 \mathrm{~h}$. Filters were washed in two changes of $0.3 \mathrm{M}$ sodium chloride $-30 \mathrm{mM}$ sodium citrate- 0.1 per cent SDS at $25^{\circ} \mathrm{C}$ for $10 \mathrm{~min}$ and two changes of $75 \mathrm{mM}$ sodium chloride $-7.5 \mathrm{mM}$ sodium citrate- $0 \cdot 1$ per cent $\operatorname{SDS}$ at $50^{\circ} \mathrm{C}$ for $1 \mathrm{~h}$ each. The filters were exposed to Kodak XAR-5 film with Dupont Cronix intensifying screens at $-70^{\circ} \mathrm{C}$. A cDNA probe consisting of the heparin-binding domain of the TSP molecule [8] was labeled with $\left[{ }^{32} \mathrm{P}\right] \mathrm{dATP}$ to a specific activity of $2-5 \times 10^{6} \mathrm{dpm} / \mathrm{ng}$ by oligo-labeling [9] and used to identify TSP-specific mRNA.

\section{Enzyme-linked immunosorbent assay (ELISA)}

ELISAs were performed to quantify the amount of TSP secreted into the culture medium by the cells. Cells were plated at $3.5 \times 10^{5}$ cells per well in growth medium and grown for 1 day. Following this, the cells were washed twice in serum-free MEM and incubated for an additional 2 or $6 \mathrm{~h}$ in MEM supplemented with $200 \mu \mathrm{g} / \mathrm{ml}$ of bovine serum albumin. The culture medium was then harvested, clarified by lowspeed centrifugation and added to wells of a 96-well plate (Falcon Plastics, Oxnard, 
CA) from lots that had been pre-screened for acceptability in ELISAs. We used $200 \mu \mathrm{l}$ per well and incubated the wells for $4 \mathrm{~h}$ at $37^{\circ} \mathrm{C}$. Serum-free MEM supplemented with $200 \mu \mathrm{g}$ of bovine serum albumin served as the negative control. Purified human platelet TSP $(0 \cdot 5-0.0005 \mu \mathrm{g}$ per well) was also added to the assay plate in the same buffer to serve as a standard. After the 4-h incubation, the culture medium from the cells and the control culture medium were removed from the wells and the ELISA was then run exactly as described previously [28]. The cells from which the culture medium was obtained were harvested with trypsin and counted.

\section{Immunofluorescence}

The tumor cells were examined for anti-TSP binding by indirect immunofluorescence 1 day after plating. For this, $2 \times 10^{5}$ cells from each line were seeded on to $20 \times 20 \mathrm{~mm}$ glass cover-slips. The culture medium consisted of MEM supplemented with 10 per cent fetal bovine serum. At the time of staining, the culture medium was removed and the cells were gently washed three times in cold PBS. All subsequent steps were carried out at $4^{\circ} \mathrm{C}$. The cells were stained initially with a $1: 20$ dilution of the rabbit anti-TSP or normal rabbit serum $(45 \mathrm{~min})$ and then washed three times. They were then stained with a $1: 50$ dilution of fluorescein-conjugated swine anti-rabbit serum ( $45 \mathrm{~min}$ ) obtained from Accurate Scientific and Chemical (Westbury, NY). Following three additional rinses in PBS, the cover-slips were placed on glass slides and viewed immediately by standard fluorescence microscopic techniques. Staining of the UM-SCC-11B cells with the monoclonal antibodies was carried out using the same protocol, but in this case the secondary stain consisted of fluorescein-conjugated goat anti-mouse serum (Accurate Scientific and Chemical).

\section{Results}

\section{TSP secretion}

ELISAs were carried out to determine the amount of TSP secreted into the culture medium by the tumor cell lines. For these studies, culture fluids from the cell lines were harvested after $2 \mathrm{~h}$ of incubation (unless indicated otherwise) and analysed for immunoreactive TSP as described under Materials and methods. The results of this study (table 1 ) indicated that the squamous carcinoma cells secreted significantly more TSP into the culture fluid than the melanoma or glioma cells. The results further showed that there was considerable variability among the squamous carcinoma lines. The most active squamous carcinoma cells (UM-SCC-11A) secreted 2-3 times more TSP than the least active squamous carcinoma line (UMSCC-22B) and approximately 20 times more than the least active melanoma line (SK-MEL-28).

\section{Cell surface TSP expression}

Immunofluorescence studies were carried out to compare cell surface expression of TSP by the tumor cell lines. The cells were grown on glass cover-slips for 1 day and then stained in the viable state with rabbit polyclonal anti-TSP. In parallel with what was seen in ELISAs, the squamous carcinoma cells exhibited more surface staining with anti-TSP than did the melanoma or glioma cells. There was, furthermore, significant variability among the squamous carcinoma lines. For example, when examined by fluorescence microscopy and simultaneously by phasecontrast microscopy, it could be seen that more than 95 per cent of the UM-SCC$11 \mathrm{~B}$ cells stained with the rabbit polyclonal anti-TSP. Punctate staining distributed 
Table 1. Immunoreactive TSP in the culture fluid of squamous carcinoma, melanoma and glioma cells ${ }^{a}$.

\begin{tabular}{lc}
\hline & $\begin{array}{c}\text { TSP } \\
\text { Cell type }\end{array}$ \\
\hline (ng/106 cells) \\
\hline Squamous carcinoma & \\
UM-SCC-1 & $95 \pm 5$ \\
UM-SCC-11A & $285 \pm 35$ \\
UM-SCC-11B & $210 \pm 27$ \\
UM-SCC-12 & $110 \pm 10$ \\
UM-SCC-22B & $90 \pm 15$ \\
UM-SCC-11B $(6 \mathrm{~h})$ & $710 \pm 14$ \\
UM-SCC-22B $(6 \mathrm{~h})$ & $120 \pm 10$ \\
Melanoma & \\
UM-MEL-1 & $25 \pm 5$ \\
SK-MEL-10 & $15 \pm 1$ \\
SK-MEL-27 & $85 \pm 10$ \\
SK-MEL-28 & $10 \pm 2$ \\
Glioma & \\
UM6 & $15 \pm 5$ \\
U138 & $75 \pm 15$ \\
\hline
\end{tabular}

${ }^{a}$ The buffer consisted of $200 \mu \mathrm{l}$ of MEM supplemented with $200 \mu \mathrm{g}$ of bovine serum albumin per ml. Human platelet TSP was added to the same buffer to generate a standard curve. The culture fluids consisted of the same buffer incubated for 2 or $6 \mathrm{~h}$ in the presence of $3.5 \times 10^{5}$ cells. The values represent ng of TSP per ml per $1 \times 10^{6}$ cells. They were obtained directly from the standard curve generated with human platelet TSP. All values are averages of duplicate wells in a single experiment \pm the differences between the individual values and the averages. The experiment was repeated three times with similar results.

over the entire surface of the cells was seen. In contrast, a much smaller proportion of the UM-SCC-22B cells (approximately 5 per cent) showed significant staining with the same antibody. The remainder of the UM-SCC-22B cells showed a very weak staining pattern. 'The UM-SCC-11A cells were similar to UM-SCC-11B whereas the other two squamous lines were intermediate between UM-SCC-11B and UMSCC-22B. Among the melanoma lines, UM-MEL-1 and SK-MEL-27 showed more staining than SK-MEL-10 and SK-MEL-28. Of the two glioma lines, U138 showed more staining than UM6. There was, therefore, a good correlation among all of the cell lines between amount of TSP secreted as indicated by ELISA and the degree of cell surface staining. None of the cell lines showed visible staining when normal rabbit serum was used in place of anti-TSP. Staining patterns seen with UM-SCC-11B, UM-SCC-22B and SK-MEL-28 are shown in figure 1.

The UM-SCC-11B cells were also stained with three mouse monoclonal antibodies against TSP. These were antibody A2.5, directed against the heparinbinding domain of the TSP molecule; antibody A6.1, which binds to the 70-kD trypsin-resistant core region of the TSP molecule; and antibody A4.1, which binds to a $45-\mathrm{kD}$ region within the $70-\mathrm{kD}$ trypsin-resistant core $[5-7,10,31]$. The staining pattern seen with $\mathrm{A} 2.5$ was very similar to that seen with the rabbit polyclonal antibody, that is, a high percentage of the cells stained in the viable state and the staining appeared uniformly distributed over the entire cell surface (figure 2). In contrast, staining with antibody A6.1 was similar in pattern but weaker (not shown) and no staining was seen with antibody A4.1 (figure 2). 

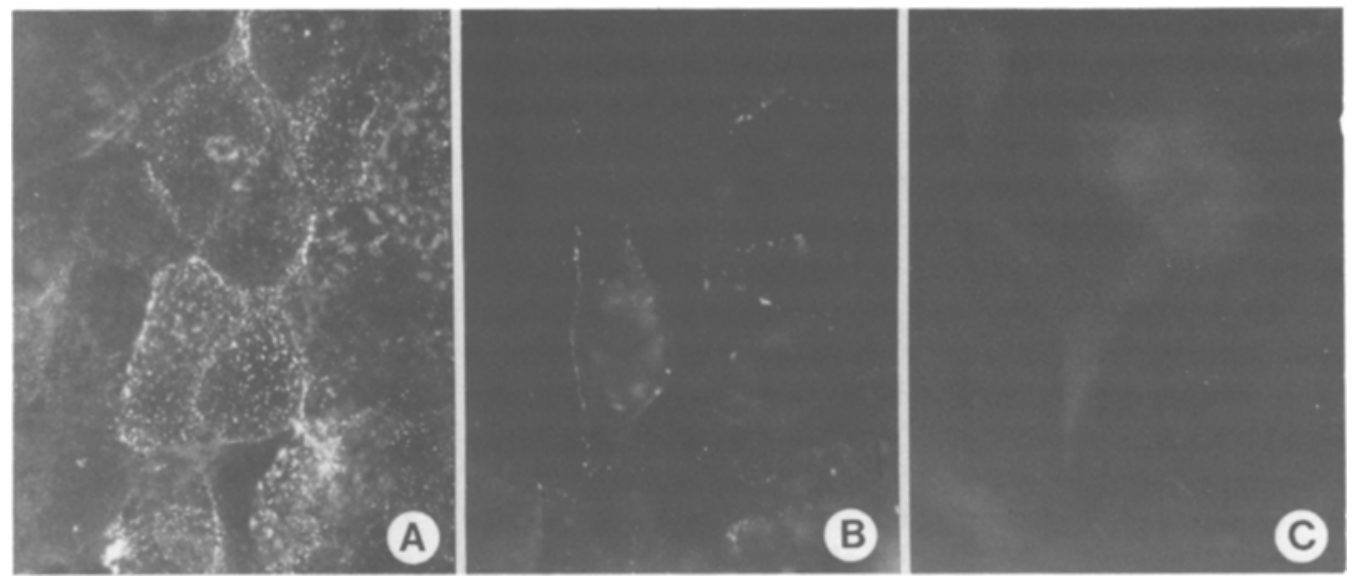

Figure 1. Immunofluorescence staining of cells in the viable state. Cells grown on coverslips for 1 day were gently washed in PBS and then stained at $4^{\circ} \mathrm{C}$ with a $1: 20$ dilution of rabbit polyclonal anti-TSP followed by a $1: 50$ dilution of fluorescein isothiocyanate conjugated swine anti-rabbit IgC. Photographs are 1 -min exposures, $\times 800$. (A) UMSCC-11B; (B) UM-SCC-22B; (C) SK-MEL-28.
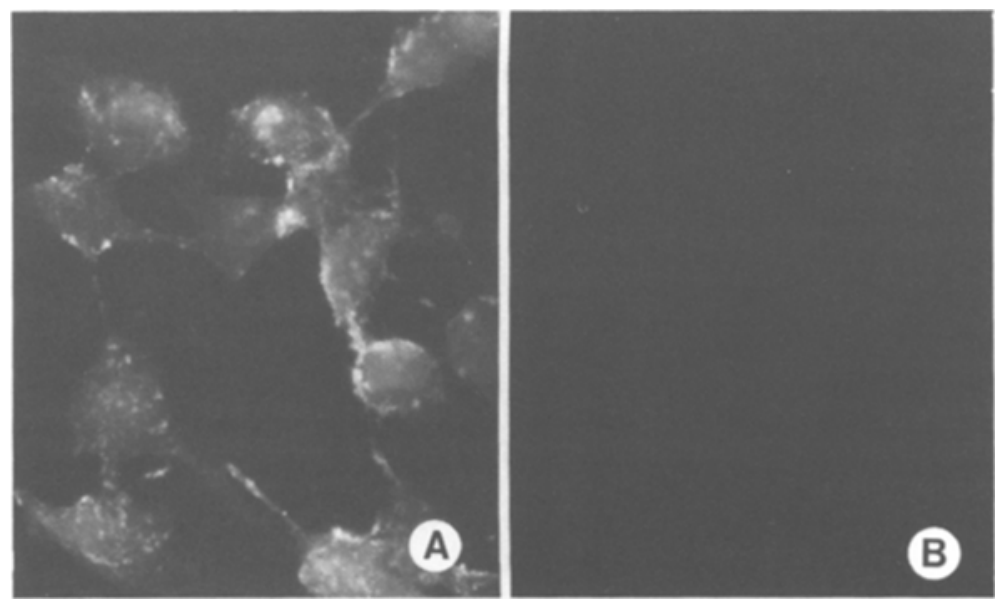

Figure 2. Immunofluorescence staining of cells in the viable state. UM-SCC-11B cells grown on cover-slips for 1 day were gently washed in PBS and then stained at $4{ }^{\circ} \mathrm{C}$ with a $1: 20$ dilution of monoclonal antibodies A2.5 and A4.1 followed by a $1: 50$ dilution of fluorescein isothiocyanate conjugated goat anti-mouse serum. Photographs are 1-min exposures, $\times 800$. (A) A2.5; (B) A4.1. 


\section{TSP biosynthesis}

In order to characterize the differences among the cell lines in TSP production more fully, three of the cell lines, UM-SCC-11B, UM-SCC-22B and SK-MEL-28, were examined for TSP biosynthesis and for production of TSP-specific mRNA. To measure biosynthesis, $\left[{ }^{35} \mathrm{~S}\right]$ methionine was incorporated into the cells using a 1-h pulse/4-h chase protocol. Detergent lysates from the cells were then examined for $\left[{ }^{35} \mathrm{~S}\right]$ methionine incorporation into forms that were immunoprecipitable with rabbit mono-specific antibodies to TSP. Under the conditions of the experiment, all three lines incorporated similar amounts of $\left[{ }^{35} \mathrm{~S}\right]$ methionine into trichloroacetic acid (TCA)-precipitable material. The amount of incorporated methionine that was precipitable with antibodies to TSP varied greatly, however, with the cell type. Autoradiograms of the immunoprecipitated material after separation by SDSPAGE under non-reducing conditions (figure 3) revealed that the UM-SCC-11B cells synthesized more TSP than the UM-SCC-22B cells. Under the same conditions, no detectable TSP synthesis was observed with the SK-MEL-28 cells. Similar differences between the three lines were also apparent on reduced gels (not shown). In order to quantitate the differences which were apparent from the autoradiograms, the radioactivity immunoprecipitated from cell extracts of each line was compared with the amount of radioactivity incorporated into TCA-precipitable material. With the UM-SCC-11B cells, approximately 0.09 per cent of the TCA-

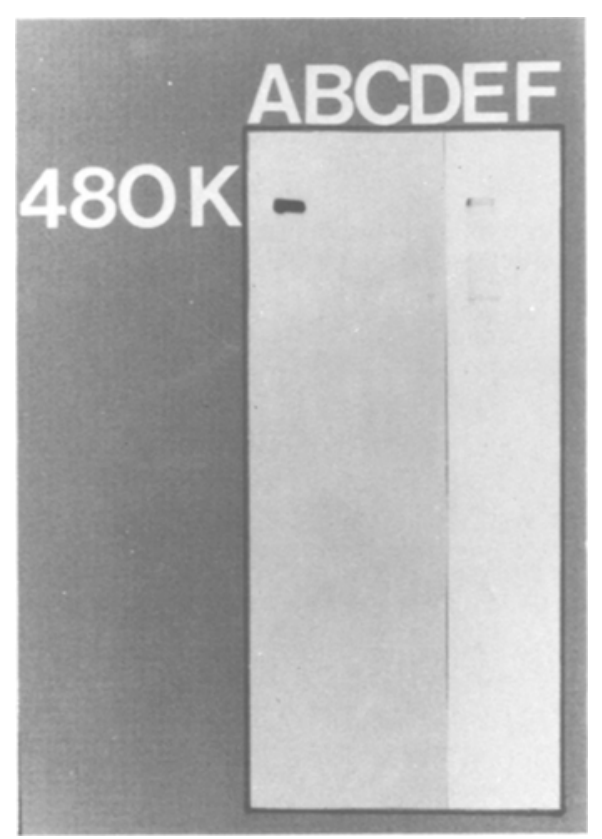

Figure 3. Immunoprecipitation of cell extracts from biosynthetically labeled UM-SCC$11 \mathrm{~B}, \mathrm{UM}-\mathrm{SCC}-22 \mathrm{~B}$ and SK-MEL-28 cells. The cells were labeled using a $1 \mathrm{-h}$ pulse/4$\mathrm{h}$ chase protocol and immunoprecipitated with polyclonal antibodies to TSP or normal rabbit serum. After solubilization, the immunoprecipitated material was separated on a 3-10 per cent gradient of SDS-PAGE under non-reducing conditions and examined by autoradiography. Left, UM-SCC-11B cells; center, SK-MEL-28 cells; right, UMSCC-22B cells. Lanes A, C and E contains anti-thrombospondin immunoprecipitates. Lanes $\mathrm{B}, \mathrm{D}$ and $\mathrm{F}$ contain normal rabbit serum precipitates. 
precipitable material was precipitated with the anti-TSP antibodies. Less than 0.01 per cent was immunoprecipitated from the UM-SCC-22B cells and there was no quantifiable material immunoprecipitated from the SK-MEL-28 cells.

In addition to the cell lysates, the culture fluids from the 1 -h pulse/4-h chase cells were examined for anti-TSP-precipitable material. Analysis of the culture fluids indicated that there was a direct relationship between the amount of immunoreactive TSP synthesized and the amount secreted (or shed) into the culture fluid. Approximately 2.5 per cent of the TCA-precipitable radioactivity in the culture fluid from the UM-SCC-11B cells was immunoprecipitated with antibodies to TSP. Only 0.4 per cent of the TCA-precipitable material in the culture fluid from the UMSCC-22B cells was immunoprecipitated under the same conditions and no antiTSP-precipitable material was detected in the culture fluid from the SK-MEL-28 cells.

Northern blot analysis. Northern blot analysis was used to determine if the differences in TSP biosynthesis between the three lines were due to alterations in the level of mRNA for TSP. A cDNA probe consisting of the heparin-binding domain of the TSP molecule [8] was used. Figure 4 shows an autoradiogram of the RNA blot prepared with two different concentrations of RNA ( $4 \mu \mathrm{g}$ per lane in A, B and C and $15 \mu \mathrm{g}$ per lane in $\mathrm{D}, \mathrm{E}$ and $\mathrm{F}$ ). When $15 \mu \mathrm{g}$ of RNA were loaded on to the gel, mRNA could be detected from both squamous carcinoma lines (lanes $\mathrm{E}$ and $\mathrm{F}$ ), but the signal was stronger with the UM-SCC-11B cells (lane F) than with the UM-SCC$22 \mathrm{~B}$ cells (lane E). No message was detected with the SK-MEL-28 cells (lane D).

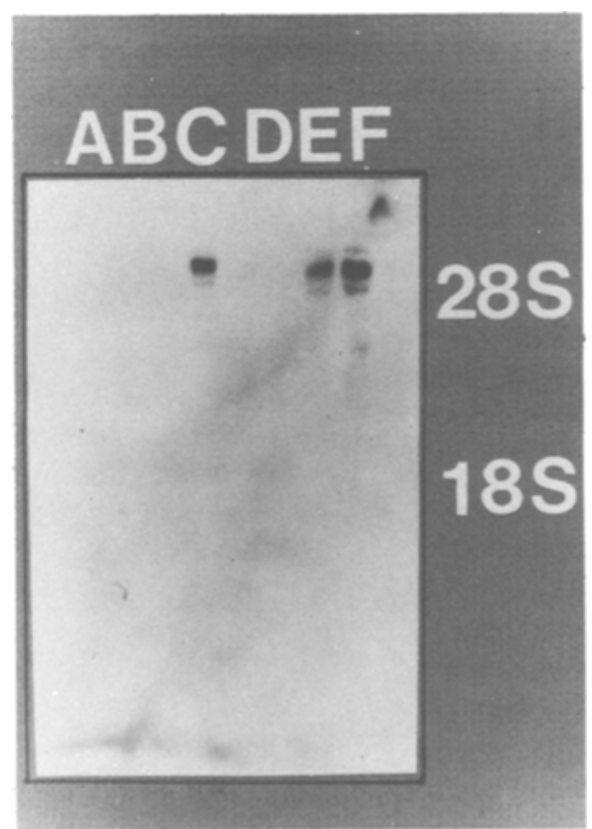

Figure 4. Northern blot analysis of RNA isolated from SK-MEL-28 cells (lanes A and D), UM-SCC-22B cells (lanes B and E) and UM-SCC-11B cells (lanes $\mathrm{C}$ and F). Total RNA ( $4 \mu \mathrm{g}$ in lanes $\mathrm{A}-\mathrm{C}$ and $15 \mu \mathrm{g}$ in lanes $\mathrm{D}-\mathrm{F}$ ) was fractionated on a 1.4 per cent formaldehyde agarose gel and transferred to a nitrocellulose membrane. The thrombospondin transcript was detected by hybridization with a ${ }^{32} \mathrm{P}$-labeled $1.2 \mathrm{~kb}$ thrombospondin probe and autoradiography. 
When $4 \mu \mathrm{g}$ of RNA were loaded on to the gel, mRNA was detected only with the UM-SCC-11B cells (lane C). Hence there was a direct relationship between the amount of TSP mRNA detected and the amount of TSP synthesized, indicating that TSP biosynthesis was regulated at the transcriptional level.

\section{Discussion}

TSP serves as an adhesion factor for a number of different types of cells [21, 27, 29-31]. Studies in our laboratory have shown that among human tumor cells, squamous carcinoma cells tend to be highly responsive to TSP whereas melanoma cells and glioma cells are less responsive or non-responsive under the same conditions $[29,30]$. Additionally, our studies have shown that tumor cells which respond to TSP also synthesize the molecule [29]. These cells simultaneously express receptors for TSP on their surface [20], thus providing a mechanism whereby the endogenously synthesized protein could be used to promote adhesion. This study is a continuation of our efforts to characterize the production of TSP by human tumor cells and the possible role of the endogenously synthesized protein in cell-substrate adhesion.

Here it is shown that levels of TSP mRNA in three cell lines correlate closely with levels of TSP synthesized by the same cells. Thus, TSP production appears to be regulated at the transcriptional level. The endogenously produced TSP is secreted into the culture medium and bound to the cell surface. There is a direct relationship between the amount of TSP biosynthesized and the amount secreted into the culture medium and bound to the cell surface. Taken together, these data indicate that several parameters related to TSP metabolism vary together. Further, when the results of this study are compared with our previous results on measuring cellsubstrate adhesion by the same cells [29, 30], they show that there is a good correlation between TSP production and responsiveness to TSP in the adhesion assay. This supports the suggestion that endogenously synthesized TSP may be used by the cells which synthesize it to promote cell-substrate adhesion. Our previous finding that adhesion of UM-SCC-11B cells to bovine serum albumin-coated dishes (i.e. in the absence of exogenous adhesion factors) could be blocked with polyclonal antibodies to TSP [29] is consistent with this view. The findings in this study that the most responsive squamous carcinoma cells secrete amounts of TSP into the culture medium that are sufficient to elicit attachment and spreading $[20,29]$ and that the kinetics of TSP secretion parallel closely the kinetics of attachment and spreading on bovine serum albumin-coated dishes [20,29] also support this suggestion.

Although these data suggest that TSP synthesized by the squamous carcinoma cells can bind to receptors on the same cells and induce cell-substrate adhesion, little is known about the nature of the receptors or how the ligand actually interacts with the cells. Studies by Asch et al. [1] have suggested that the antigen which reacts with the OKM5 monoclonal antibody serves as a TSP receptor on some cells. Others have suggested that cell-surface heparan sulfate proteoglycans are responsible for TSP binding $[17,18]$. In our studies with squamous carcinoma cells, we have been unable to demonstrate inhibition of TSP binding (unpublished observation) or TSPinduced attachment and spreading with OKM5 antibody [31]. On the other hand, a monoclonal antibody directed against the heparin-binding domain of TSP (e.g. antibody A2.5) was shown in our previous studies partially to inhibit attachment and spreading of squamous carcinoma cells on bovine serum albumin-coated dishes. This antibody was not able to block attachment and spreading on dishes coated with 
exogenous TSP, however $[29,31]$. In this study it was found that this antibody reacts strongly with squamous carcinoma cells in the viable state. In contrast, two other antibodies (e.g. A6.1 and A4.1), which are potent inhibitors of TSP induced attachment and spreading [29, 31], were much less effective (A6.1) or failed completely (A4.1) to stain cells in the viable state. Taken together, these data suggest that the heparin-binding domain of the TSP molecule (which is known from other studies to reside in a peripheral region of the intact molecule [10]) is exposed on viable cells. In contrast, the core region of the molecule (recognized by antibodies A6.1 and A4.1) may reside in a portion of the molecule which is relatively unexposed on the cell surface. As the antibodies which bind to this region of the molecule (A6.1 and A4.1) are effective inhibitors of TSP-induced attachment and spreading, this may suggest that there is a cell binding domain in this region of the molecule and that interaction of this cell binding domain with its binding site on the cell surface stimulates adhesion. Alternatively, the TSP molecule is known to undergo conformational changes which alter its interaction with certain monoclonal antibodies [7]. The conformational state of the molecule on the cell surface may be such that it is not capable of interacting with antibody A4.1. Studies to distinguish between these possibilities are in progress.

\section{Acknowledgments}

This study was supported in part by grants PDT-324 from the American Cancer Society and CA28564 from the USPHS and by grant from the Veterans Administration. T. E. Carey is a recipient of USPHS RCDA CA00621.

\section{References}

[1] Asch, A. S., Barnwell, J., Silverstein, R. L., and NaChman, R. L., 1987, Isolation of the thrombospondin membrane receptor. Journal of Clinical Investigation, 79, 1054-1061.

[2] Carey, T. E., Takahashi, T., Resnick, L. A., Oettgen, H. F., and Old, L. J., 1976, Cell surface antigens of human malignant melanoma: mixed hemadsorption assays for humoral immunity to cultured autologous melanoma cells. Proceedings of the National Academy of Sciences of the U.S.A., 73, 3278-3282.

[3] Chirgwin, J. M., Przybyla, A. E., MacDonald, R. J., and Ruttler, W. J., 1979, Isolation of biologically active ribonucleic acid from sources enriched in ribonuclease. Biochemistry, 24, 5294-5299.

[4] Dixit, V. M., Grant, G. A., Santoro, S. A., and Frazier, W. A., 1984, Isolation and characterization of a heparin-binding domain from the amino terminus of platelet thrombospondin. Journal of Biological Chemistry, 259, 10100-10105.

[5] Dixit, V. M., Haverstick, D. M., O’Rourke, K. M., Hennessy, S. W., Grant, G. A., SANTARo, S. A., and Frazier, W. A., 1985, Effects of anti-thrombospondin monoclonal antibodies on the agglutination of erythrocytes and fixed activated platelets by purified thrombospondin. Biochemistry, 24, 4270-4275.

[6] Dixit, V. M., Haverstick, D. M., O'Rourke, K. M., Hennessy, S. W., Grant, G. A., Santoro, S. A., and Frazier, W. A., 1985, Inhibition of platelet aggregation by a monoclonal antibody against human fibronectin. Proceedings of the National Academy of Sciences of the U.S.A., 82, 3844-3848.

[7] Dixit, V. M., O'Rourke, K. M., Grant, G. A., Santoro, S. A., and Frazier, W. A., 1986, Monoclonal antibodies that recognize calcium-dependent structures of human thrombospondin with EM and high sensitivity amino acid sequencing. Journal of Biological Chemistry, 261, 1962-1968.

[8] Dixit, V. M., Hennessy, S. W., Grant, G. A., Rotwein, P., and Frazier, W. A., 1986, Characterization of a cDNA encoding the heparin and collagen binding domains of human thrombospondin. Proceedings of the National Academy of Sciences of the U.S.A., 83, 5449-5453. 
[9] Feinberg, A., and Vogelstein, B., 1983, A technique for radiolabeling DNA restriction endonuclease fragments to high specific activity. Analytical Biochemistry, 132, 6-13.

[10] Galvin, N. J., Dixit, V. M., O’Rourke, K. M., Santoro, S. A., Grant, G. A., and Frazier, W. A., 1985, Mapping of epitopes for monoclonal antibodies against human platelet thrombospondin. Journal of Cell Biology, 101, 1434-1441.

[11] Jaffe, E. A., Ruggiero, J. T., Leung, L. L. K., Doyle, M. J., McKeown-Longo, P. J., and Mosher, D. F., 1983, Cultured human fibroblasts synthesize and secrete thrombospondin and incorporate it into extracellular matrix. Proceedings of the National Academy of Sciences of the U.S.A., 80, 990-1002.

[12] Kimmel, K. A., and Carey, T. E., 1986, Altered expression in squamous carcinoma cells of an orientation restricted epithelial antigen detected by monoclonal antibody A9. Cancer Research, 46, 3614-3623.

[13] LaEmmLi, U. K., 1970, Cleavage of structural proteins during the assembly of the head of bacteriophage T4. Nature (London), 227, 680-685.

[14] McKeever, P. E., Fligiel, S. E. G., Varani, J., Hudson, J. L., Smith, D., Castle, R. L., and McCoy, J. P., 1986, Products of cells cultured from gliomas. IV. Extracellular matrix products of gliomas. International Journal of Cancer, 37, 867-874.

[15] McPherson, J., Sage, H., and Bornstein, P., 1981, Isolation and characterization of glycoproteins secreted by aortic endothelial cells in culture. Journal of Biological Chemistry, 256, 1130-1136.

[16] Mosher, D. F., Doyle, M. J., and JAFFe, E. A., 1982, Synthesis and secretion of thrombospondin by cultured human endothelial cells. Journal of Cell Biology, 93, 243-348.

[17] Murphy-Ullrich, J. E., Westrick, L. G., Esko, J. D., and Mosher, D. F., 1986, Binding of thrombospondin (TSP) to Chinese hamster ovary (CHO) cell mutants defective in glycoaminoglycan (GAG) biosynthesis. Journal of Cell Biology, 103, 93a.

[18] Murphy-Ullrich, J. E., and Mosher, D. F., 1987, Interactions of thrombospondin with endothelial cells: receptor-mediated binding and degradation. Journal of Cell Biology, 105, 1603-1609.

[19] Raugi, G. J., Mumby, S. M., Abbott-Brown, D., and Bornstein, P., 1982, Thrombospondin: synthesis and secretion by cells in culture. Journal of Cell Biology, 95, 351-354.

[20] Riser, B. L., Varani, J., O'Rourke, K., and Dixit, V. M., 1988, Thrombospondin binding by human squamous carcinoma and melanoma cells: relationship to biological activity. Experimental Cell Research, 174, 319-329.

[21] Roberts, D. D., Sherwood, J. A., and Ginsburg, V., 1987, Platelet thrombospondin mediates attachment and spreading of human melanoma cells. Journal of Cell Biology, 104, 131-140.

[22] Ronnett, G. V., Knutson, V. P., Kohnski, R. A., Simpson, T. L., and Lane, M. D., 1984 , Role of glycosylation in the processing of newly translated insulin proreceptor in 3T3-L1 adipocytes. Journal of Biological Chemistry, 259, 4566-4576.

[23] Ruddon, R. W., Hanson, C. A., and Addison, N. J., 1979, Synthesis and processing of human chorionic gonadotropin subunits in cultured choriocarcinoma cells. Proceedings of the National Academy of Sciences of the U.S.A., 76, 5173-5176.

[24] Sage, H., Farin, F. M., Striker, G. E., and Fisher, A. B., 1983, Granular pneumocytes in primary culture secrete several major components of the extracellular matrix. Biochemistry, 22, 2148-2155.

[25] Silverstein, R. L., and Nachman, R. L., 1987, Thrombospondin binds to monocytesmacrophages and mediates platelet-monocyte adhesion. Journal of Clinical Investigation, 79, 862-874.

[26] Thомаs, P., 1980, Hybridization of denatured RNA and small DNA fragments transferred to nitrocellulose. Proceedings of the National Academy of Sciences of the U.S.A., 77, 5201-5205.

[27] Tuszynski, G. P., Rothman, V. L., Murphy, A., Seigler, K., Smith, S., Smiths, J., KaRCZEwsKI, J., and KNUDSEN, K. A., 1987, Thrombospondin promotes cell-substrate adhesion. Science, 236, 1570-1573.

[28] Varani, J., Lovett, E. J., McCoy, J. P., Shibata, S., Maddox, D., Goldstein, I. J., and WiCHA, M., 1983, Differential expression of a laminin-like substance by high- and low-metastatic tumor cells. American Journal of Pathology, 111, 27-34. 
[29] Varani, J., Dixit, V. M., Fligiel, S. E. G., McKeever, P. E., and Carey, T. E., 1986, Thrombospondin-induced attachment and spreading of human squamous carcinoma cells. Experimental Cell Research, 167; 376-390.

[30] Varani, J., Carey, T. E., Fligiel, S. E. G., McKeever, P. E., and Dixit, V., 1987, Tumor type-specific differences in cell-substrate adhesion among human tumor cells. International Journal of Cancer, 39, 397-403.

[31] Varani, J., Nickoloff, B. J., Riser, B. L., Mitra, R. S., O'Rourke, K., and Dixit, V. M., 1988, Thrombospondin-induced adhesion of human keratinocytes. Journal of Clinical Investigation, 81, 1537-1544. 